\title{
Technical Note: A fully automated purge and trap GC-MS system for quantification of volatile organic compound (VOC) fluxes between the ocean and atmosphere
}

\author{
S. J. Andrews, S. C. Hackenberg, and L. J. Carpenter \\ Wolfson Atmospheric Chemistry Laboratories, Department of Chemistry, The University of York, York, YO105DD, UK \\ Correspondence to: S. J. Andrews (stephen.andrews@york.ac.uk)
}

Received: 5 November 2014 - Published in Ocean Sci. Discuss.: 19 December 2014

Revised: 16 March 2015 - Accepted: 22 March 2015 - Published: 23 April 2015

\begin{abstract}
The oceans are a key source of a number of atmospherically important volatile gases. The accurate and robust determination of trace gases in seawater is a significant analytical challenge, requiring reproducible and ideally automated sample handling, a high efficiency of seawater-air transfer, removal of water vapour from the sample stream, and high sensitivity and selectivity of the analysis. Here we describe a system that was developed for the fully automated analysis of dissolved very short-lived halogenated species (VSLS) sampled from an under-way seawater supply. The system can also be used for semi-automated batch sampling from Niskin bottles filled during CTD (conductivity, temperature, depth) profiles. The essential components comprise a bespoke, automated purge and trap (AutoP \& T) unit coupled to a commercial thermal desorption and gas chromatograph mass spectrometer (TD-GC-MS). The AutoP \& T system has completed five research cruises, from the tropics to the poles, and collected over 2500 oceanic samples to date. It is able to quantify $>25$ species over a boiling point range of 34 $180^{\circ} \mathrm{C}$ with Henry's law coefficients of 0.018 and greater $\left(\mathrm{CH}_{2} \mathrm{I}_{2}, k_{\mathrm{H}}^{\mathrm{cc}}\right.$ dimensionless gas/aqueous $)$ and has been used to measure organic sulfurs, hydrocarbons, halocarbons and terpenes. In the eastern tropical Pacific, the high sensitivity and sampling frequency provided new information regarding the distribution of VSLS, including novel measurements of a photolytically driven diurnal cycle of $\mathrm{CH}_{2} \mathrm{I}_{2}$ within the surface ocean water.
\end{abstract}

\section{Introduction}

The ocean covers $>70 \%$ of the Earth's surface and is an important natural source of a wide range of trace gases, notably those containing sulfur, nitrogen and halogens. These play critical roles in global biogeochemical cycling and in a wide range of atmospheric processes including marine aerosol formation and modification, tropospheric ozone formation and destruction, and stratospheric ozone loss (Davis et al., 1998; von Glasow et al., 2004; Yang et al., 2005; Read et al., 2008; McFiggans et al., 2010; Montzka et al., 2011; Saiz-Lopez et al., 2012; Santos and Rast, 2013).

A number of ocean biological and chemical processes are responsible for the production of marine gases. Very shortlived halogenated species (VSLS), which deliver ozonedepleting reactive halogens to the troposphere and lower stratosphere, can be released from marine macro algae, from phytoplankton, from marine bacteria and detritus and via photochemical breakdown of dissolved organic matter (DOM) in the surface ocean (Sturges et al., 1993; Schall et al., 1994; Tokarczyk and Moore, 1994; Happell and Wallace, 1996; Goodwin et al., 1997; Carpenter et al., 2000; Carpenter and Liss, 2000; Richter and Wallace, 2004; Hughes et al., 2008; Chance et al., 2009; Asare et al., 2012; Ordóñez et al., 2012; Leedham et al., 2013).

Water bodies may also contain anthropogenic components such as trihalomethanes (THMs), aromatic hydrocarbons, pesticides and waste pharmaceuticals which must be closely monitored and have legally enforceable limits (DEFRA, 2000). These contaminants are a direct concern for human health and as such are often targeted by established 
methods (e.g. US EPA, 2010, WHO - Thompson et al., 2007) and routine measurements of in-land water bodies.

Many marine trace gases exhibit large spatial and temporal variation in their concentrations and emissions, which necessitates the collation of large data sets in order to capture these trends on a global scale and quantify their role in the atmosphere (e.g. https://halocat.geomar.de/). This paper describes an instrument designed to quantify the concentrations of VSLS in the ocean with sufficient temporal resolution to capture diurnal emission profiles and the precision to accurately determine patterns in their spatial distribution.

\section{Methods}

In situ VOC seawater measurements are typically made using manual purge and trap gas chromatography methods (e.g. Ledyard and Dacey, 1994; Quack et al., 2004; Jones et al., 2009) or via online equilibrator techniques with analysis by pre-concentration GC-MS or chemical ionisation mass spectrometry (Saltzman et al., 2009; Beale et al., 2011; Kameyama et al., 2014). Equilibrator techniques include Weiss-type (Johnson, 1999; Butler et al., 2007; Kameyama et al., 2010), which employs direct contact between the liquid and gas phases, or membrane-type (Groszko and Moore, 1998; Loose et al., 2009; Yang et al., 2014), which physically separates the phases, with the analytes able to pass through the gas permeable membrane. The latter offers the advantage of reduced water vapour in the gas phase, especially if a hydrophobic membrane is used.

A disadvantage of the equilibrator technique is that it is limited to analytes with quite high volatilities. Purge and trap samples however can be heated and extensively purged to remove the analytes, such that compounds with boiling points greater than $180^{\circ} \mathrm{C}$ can be efficiently sampled. However, this often introduces a large amount of water vapour into the instrument, is aggressive toward any biological life in the sample and requires sample preparation and constant operator attention. An automated purge and trap system involves mechanical handling of the sample and requires mechanisms to prevent salt, biological life and debris from blocking valves and fouling tubing.

\subsection{Instrument design}

Manual water sampling is still commonly used for purge and trap systems (Quack et al., 2007; Raimund et al., 2011). Automation of a method removes sources of human error, allows continuous $24 \mathrm{~h}$ sampling and can improve reproducibility. Just as important and often overlooked is the reduction in workload that automation can bring, allowing time for the analyst to concentrate on the upkeep of the instrument and the interpretation of the data.

An automated purge and trap system (AutoP \& T) was developed for the analysis of VSLS in seawater. This allows for the measurement of trace gases, not limited to VSLS, in any liquid sample, but was designed predominantly for operation on-board research ships sampling seawater from pumped underway supplies and discrete samples taken directly from the ocean. The AutoP \& T was coupled to a commercial thermal desorption unit (TD, Markes Unity2-CIA8), and an Agilent 6850 gas chromatograph (GC) with a 5975C mass selective detector (MSD), but can be used with any TD-GC instrument.

The system employs the commonly used glass purge tube design with a nitrogen or helium carrier gas for sparging dissolved gases from the liquid sample. The purge tube is thermostatic at $50^{\circ} \mathrm{C}$ using PID (proportional-integralderivative) controlled high temperature heating rope (Omega, FGR). As is the case for direct air analysis, the gas sample is pre-concentrated onto the cooled $\left(-30^{\circ} \mathrm{C}\right)$ absorbent trap (Tenax TA) of the TD unit. All analytes were quantitatively trapped during breakthrough tests using sample volumes up to $3 \mathrm{~L}$ with these conditions. The sample was desorbed at $250^{\circ} \mathrm{C}$ onto the GC column $(60 \mathrm{~m} 320 \mu \mathrm{m}$ Internal Diameter (I.D.) $1 \mu \mathrm{m} 5 \%$ phenyl film, SGE). The column was held at $40^{\circ} \mathrm{C}$ for $2 \mathrm{~min}$, ramped at $20^{\circ} \mathrm{C} \mathrm{min}^{-1}$ to $207^{\circ} \mathrm{C}$, then at $100^{\circ} \mathrm{Cmin}^{-1}$ to $250^{\circ} \mathrm{C}$. The MSD was operated in SIM/SCAN mode with 19 selected ion windows monitoring a total of 46 ions, and a qualifier and quantifier per analyte. The MSD source and quadrupole temperatures were increased to 250 and $200^{\circ} \mathrm{C}$, respectively, and an enlarged $6 \mathrm{~mm}$ draw out plate was fitted to counter MSD sensitivity stability issues associated with water sampling.

\subsection{Ship-borne installation and automation}

The pumped underway water supply varies with research vessel but usually consists of an inlet positioned at the bow around $6 \mathrm{~m}$ below sea level to allow for pitching and rolling of the ship without introduction of air to the inlet. For the RSS James Clark Ross (JCR), in which the AutoP \& T has been fitted on two occasions, the water is pumped at a high flow rate into the laboratories $\left(>200 \mathrm{~L} \mathrm{~min}^{-1}\right)$. From this a proportion was diverted to the AutoP \& T via a stainless steel mesh filter $(400 \mu \mathrm{m})$ to remove small particulate matter, drawn by a peristaltic pump (Watson Marlow, 1208/DV). The remaining supply was allowed to flow to waste.

The automated control of the system is achieved using just three solenoid valves. A two-way PEEK diaphragm valve (valve C, Fig. 1, BioChem 100T2NC24-62-5P) allows purge gas to flow through the system to waste. Two pinch valves, one dual-channel three-way (BioChem 100PD3MP24-02S) and one single-channel three-way (BioChem 100P3MP24$02 \mathrm{~S}$ ), are used to control the multiple water flow paths through the system and are configured to allow a flow at all times to ensure a fresh sample (Fig. 1). The three valves allow the user to filter the sample, fill/empty the glass purge tube, de-gas a liquid to waste, de-gas and trap the analytes for analysis, or to flush the purge tube with carrier gas. Pinch 


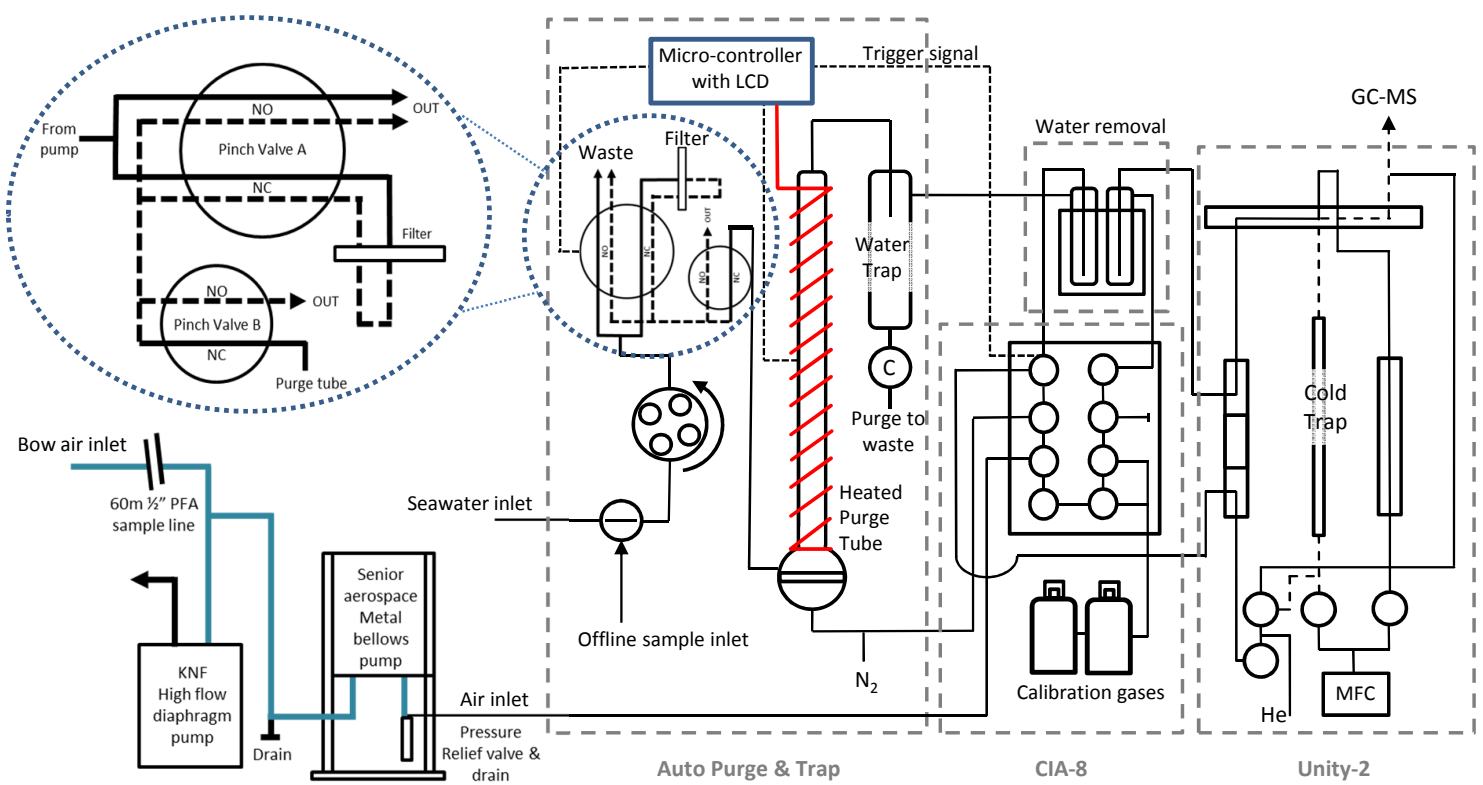

Figure 1. Flow path schematic of the AutoP \& T TD-GC-MS system with the "coldfinger" water removal system. Red lines represent electrical connections. Expanded circle: water sample flow paths through the two three-way pinch valves used to automate the purge and trap process. Bottom left: pressurised air sample introduction from the bow inlet.

valves are used as they have no wetted parts, and so are robust and the tubing can easily be replaced if contaminated. Early iterations of the instrument used polytetrafluoroethylene (PTFE) diaphragm valves (BioChem 150L3MP24-156). However, the soft PTFE diaphragm was easily damaged by flow path debris, causing leaks, and microbial growth could not easily be cleaned from the inside of the valve.

The valves, heated lines and the temperature of the purge tube are controlled by an open-source microprocessor $(\mathrm{Ar}-$ duino Uno) and the programming code is available in the Supplement. A glass water trap is incorporated after the purge tube as an overflow safety and any condensation is emptied by valve $\mathrm{C}$ at the end of each run. Water removal is necessary and is incorporated before and after the CIA8 unit of the TD (Fig. 4 and Sect. 2.3).

The system can run in one of two modes, inline or discrete. Inline mode refers to sampling from the underway supply. Discrete samples are introduced manually directly into the purge tube or semi-automated via the offline sample inlet (Fig. 1). In either scenario, sampling is started by a trigger from the TD unit, which in turn waits for the GC system to become ready. The timing of the system is shown in Fig. 3. Purge gas passes through the purge tube, water removal system, TD and out to waste. During this time the water sample is diverted through the filter $(0.45$ micron PTFE or grade glass fiber filter (GF/F) application dependent), which has a maximum pore diameter of 0.45 micron, capturing any phytoplankton (larger than 0.45 micron, Bouteiller et al., 1992) and also retaining smaller species such as picoplankton in its smaller pores. Biological matter removal is important as it can produce VOC within the heated purge tube. The carrier gas is then diverted onto the pre-concentration trap and the water sample stream diverted to fill the purge tube. Any VOCs de-gassed during the purge tube filling stage are trapped for analysis. During filling, the power available for the temperature control of the purge tube is increased to allow rapid equilibration $\left(\approx 0.5^{\circ} \mathrm{C}\right.$ deviation $)$ of the water sample to the purge temperature set point. Once the purge tube is filled the sample is purged for the remaining time and the sample flow is diverted to waste. After the sample is completely de-gassed, the flow through the purge tube stops and the pressure increases. This pressure is then used to empty the contents of the purge tube out to waste in preparation for the next sample.

In order to calculate ocean-atmospheric fluxes, air samples were acquired between each water sample. Air was drawn from a bow inlet through $1 / 2 "(12.7 \mathrm{~mm})$ PFA tubing at approx. $35 \mathrm{~L} \mathrm{~min}^{-1}$ using a diaphragm pump (KNF, N035.1.2AN.18). Before the air reached this pump it was drawn through a clean stainless steel bellows pump (Senior Aerospace, MB-158) and pressurised into the thermal desorption unit at $70 \mathrm{kPa}(10 \mathrm{psi})$ with the majority of flow vented via a proportional relief valve.

\subsection{Water removal}

The purging of water at elevated temperatures produces a large amount of water vapour that must be removed before entering the GC-MS. If the absorbent pre-concentration trap is cooled to below the dew point of the sample gas, a drying step is required pre-trapping. This was done us- 


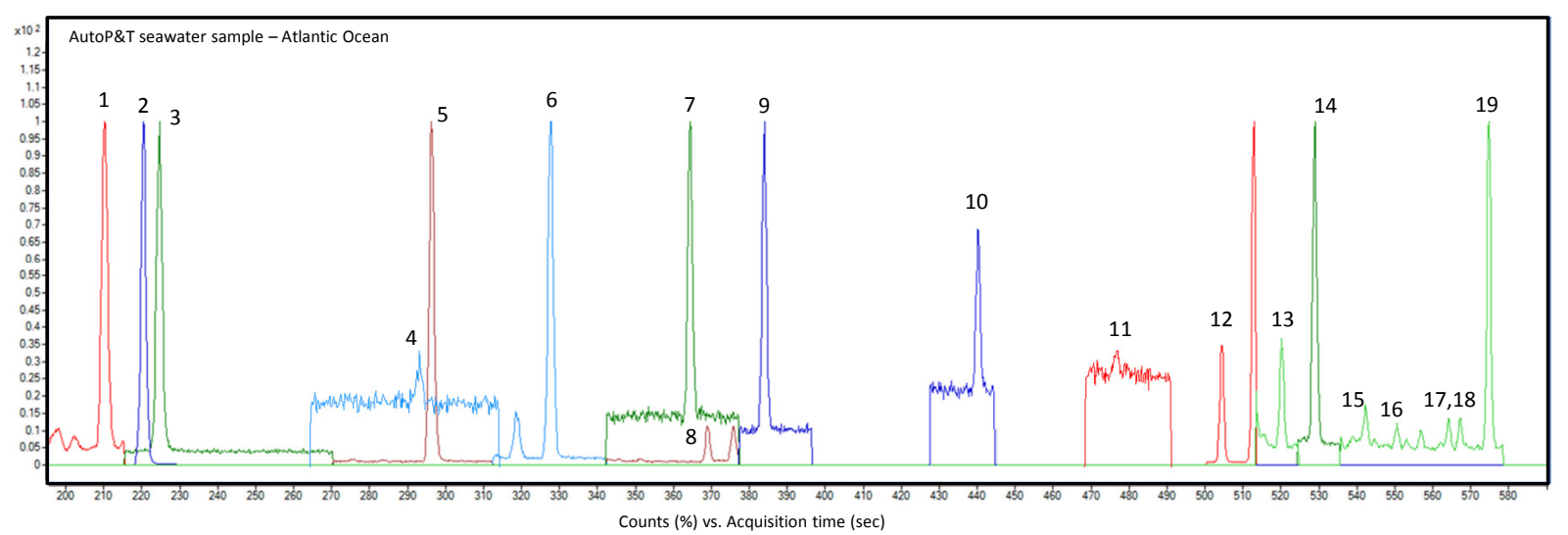

Figure 2. Example Atlantic Ocean seawater chromatogram obtained using the AutoP \& T with extracted ions individually scaled. Compound names of peak labels are listed in Table 1.

ing two different techniques, depending upon which analytes were being monitored. For halocarbons, non-oxygenated saturated hydrocarbons, DMS and isoprene, an $\mathrm{ME}^{\mathrm{TM}}$-series Nafion ${ }^{\circledR}$ moisture exchanger and a counter-flow $\mathrm{MD}^{\mathrm{TM}}$ series Nafion ${ }^{\circledR}$ gas drier (Permapure ${ }^{\mathrm{TM}}$ ) were used in series.

For oxygenated, unsaturated hydrocarbons and monoterpenes, in addition to the species mentioned previously, a glass cold trap ("coldfinger") was used to selectively remove the water whilst maintaining sample integrity in comparison with the Nafion, through which these species are lost or transformed. This type of trap has previously been used for hydrocarbon and DMS analyses (Ledyard and Dacey, 1994; Lidster et al., 2014). The analyte recovery using the two sample drying techniques, Nafion and "coldfinger", is listed in Table 1.

The coldfinger trap was cooled to $-30^{\circ} \mathrm{C}$ using either an ethylene glycol chiller (Grant R3) or a free piston Stirling cooler (Twinbird, SC-UD08 FPSC). The latter was implemented for use aboard the research ships, as it does not contain liquid and the power consumption is only around $30 \mathrm{~W}$ at $-30^{\circ} \mathrm{C}$. The glass cold trap system was tested for losses by the analysis of dry standard gas passed through or bypassing the water trap whilst ice from previous samples was present in the trap. No significant losses were observed for any of the analytes of interest. For monoterpene and halocarbon integrity it is important that the sample lines are heated as physically close as possible to the cooled water trap and that the transition between hot and cold is very rapid. This minimises the amount of liquid water into which the analytes can partition. It was found that, below $-40{ }^{\circ} \mathrm{C}$, monoterpenes and xylenes began to be lost in the coldfinger trap.

\subsection{Reproducibility}

In order to reduce the amount of water vapour entering the system, decrease purge time and maximise purge efficiency, the lowest volume of a sample should be used that provides a signal above the system's limit of detection (LOD, Table 1). This becomes an important consideration when designing the purge tube, as the out-gassing of analytes from the sample is dependent upon partitioning between the liquid and gas phases. Assuming the carrier gas is never saturated, the rate of removal of analyte from the sample is dependent upon four factors: the total surface area of all the bubbles that sparge the sample, its temperature, the time in which the gas contacts the sample and the Henry's law constant of the analyte. Therefore the purge tube was designed long and thin so that the sample filled the tube, allowing for a longer gas-liquid contact time. The carrier gas enters the tube through a quartz frit (porosity 3 ), which produces numerous small bubbles to maximise surface area.

The subtleties of the sparging method can have a significant influence on reproducibility. Bubbles reach terminal velocity shortly after formation (Leifer et al., 2000). This terminal velocity is determined by a combination of the bubble's drag and its buoyancy. Whereas buoyancy is relative to the gas that forms the bubble, drag is dependent upon bubble size and viscosity of the liquid. Water becomes less viscous at higher temperatures, increasing velocity. Increasing temperature also results in oscillation of the bubble, increasing its velocity but reducing its rise time. For bubbles larger than $2 \mathrm{~mm}$, rise time is independent of temperature (Leifer et al., 2000). Bubbles should be small and numerous to ensure maximum surface area. Bubble size generated in this system is dependent upon sparge gas pressure and the porosity of the quartz frit, which are both kept constant. However, due to its effect upon the analytes Henry's law constant, the bubble's trajectory and the viscosity of the water, it becomes increasingly apparent that accurate temperature control is vital if de-gassing is to be reproducible. 
Table 1. Individual compound purge efficiencies using AutoP \& T, associated data, water removal analyte recoveries and limits of detection (LOD).

\begin{tabular}{|c|c|c|c|c|c|c|c|c|c|c|c|}
\hline Label & Compound & $\begin{array}{r}\text { Retention } \\
\text { time }\end{array}$ & $k_{\mathrm{H}}^{\mathrm{cc}}$ & $\begin{array}{r}\text { B. pt. (K) } \\
\text { NIST }\end{array}$ & $\begin{array}{r}\% \text { purge eff. } \\
84 \mathrm{~mL}\end{array}$ & $\begin{array}{c}\% \mathrm{RSD} \\
84 \mathrm{~mL}\end{array}$ & $\begin{array}{r}\% \text { purge eff. } \\
20 \mathrm{~mL}\end{array}$ & $\begin{array}{c}\% \text { RSD } \\
20 \mathrm{~mL}\end{array}$ & $\begin{array}{r}\% \text { coldfinger } \\
\text { recovery }\end{array}$ & $\begin{array}{l}\% \text { Nafion } \\
\text { recovery }\end{array}$ & $\begin{array}{r}\text { LOD } \\
\left(\mathrm{pmol} \mathrm{L}^{-1}\right)\end{array}$ \\
\hline 1 & Isoprene & 219.4 & $1.461^{\mathrm{a}}$ & 307 & 96 & 1.7 & 97 & 0.7 & 98 & 99 & 0.1 \\
\hline 2 & DMS & 229.5 & $0.085^{\mathrm{a}}$ & 311 & 89 & 2.2 & 100 & 0.2 & 105 & 92 & 0.6 \\
\hline 3 & $\mathrm{CH}_{3} \mathrm{I}$ & 234.1 & $0.292^{\mathrm{a}}$ & 316 & 92 & 5.4 & 83 & 9.4 & 100 & 95 & 0.05 \\
\hline 4 & $\mathrm{CH}_{2} \mathrm{BrCl}$ & 303.5 & - & 341 & 85 & 4.5 & 100 & 2.7 & 104 & 94 & 0.05 \\
\hline 5 & $\mathrm{CHCl}_{3}$ & 304.9 & $0.151^{\mathrm{a}}$ & 334 & 91 & 2.9 & 83 & 6.9 & 98 & 98 & 0.02 \\
\hline 6 & $\mathrm{CCl}_{4}$ & 335.6 & $1.076^{\mathrm{a}}$ & 350 & 93 & 4.7 & 100 & 0.2 & 104 & 98 & 0.02 \\
\hline 7 & $\mathrm{CH}_{2} \mathrm{Br}_{2}$ & 373.4 & $0.044^{\mathrm{a}}$ & 370 & 68 & 4.6 & 98 & 2.4 & 102 & 93 & 0.06 \\
\hline 8 & $\mathrm{CHBrCl}_{2}$ & 378.1 & $0.102^{\mathrm{a}}$ & 363 & 94 & 2.8 & 99 & 3.1 & 98 & 99 & 0.04 \\
\hline 9 & $\mathrm{CH}_{2} \mathrm{ICl}$ & 393.3 & $0.046^{\mathrm{a}}$ & 381 & 69 & 2.8 & 100 & 0.7 & 104 & 93 & 0.06 \\
\hline 10 & $\mathrm{CHBr}_{2} \mathrm{Cl}$ & 449.6 & $0.056^{\mathrm{a}}$ & 390 & 78 & 2.3 & 100 & 1.0 & 99 & 92 & 0.04 \\
\hline 11 & $\mathrm{CH}_{2} \mathrm{IBr}$ & 461.2 & - & 405 & 53 & 3.4 & 98 & 1.6 & 100 & 91 & 0.06 \\
\hline 12 & $\mathrm{CHBr}_{3}$ & 516.8 & $0.029^{a}$ & 422 & 57 & 1.8 & 98 & 0.4 & 98 & 91 & 0.02 \\
\hline 13 & $\alpha$-pinene & 531.4 & $0.835^{\mathrm{a}}$ & 430 & 100 & 1.4 & 99 & 1.6 & 96 & 1 & 0.1 \\
\hline 14 & $\mathrm{CH}_{2} \mathrm{I}_{2}$ & 541.9 & $0.018^{\mathrm{a}}$ & 279 & 43 & 3.1 & 91 & 1.5 & 99 & 101 & 0.04 \\
\hline 15 & Myrcene & 554.8 & $1.290^{\mathrm{b}}$ & 440 & 100 & 9.0 & 100 & 20.1 & 89 & 0 & 0.3 \\
\hline 16 & $\beta$-pinene & 562.8 & $0.650^{\mathrm{b}}$ & 440 & 100 & 0.6 & 96 & 3.2 & 90 & 0 & 0.2 \\
\hline 17 & Carene & 577.0 & $0.613^{\mathrm{b}}$ & 447 & 100 & 1.3 & 94 & 0.1 & 93 & 0 & 0.2 \\
\hline 18 & Ocimene & 580.6 & $1.179^{b}$ & 448 & 97 & 1.8 & 100 & 5.2 & 95 & 0 & 0.4 \\
\hline 19 & Limonene & 588.0 & $0.804^{\mathrm{b}}$ & 451 & 100 & 2.1 & 98 & 3.3 & 89 & 0 & 0.3 \\
\hline
\end{tabular}

a Where available, Henry's law constants reproduced from the compiled list by Sander (1999).

${ }^{\mathrm{b}}$ Calculated assuming vapour pressure of $0.003 \mathrm{~atm}$ and using the AIOMFAC model (http://www.aiomfac.caltech.edu, Zuend et al., 2008, 2011).

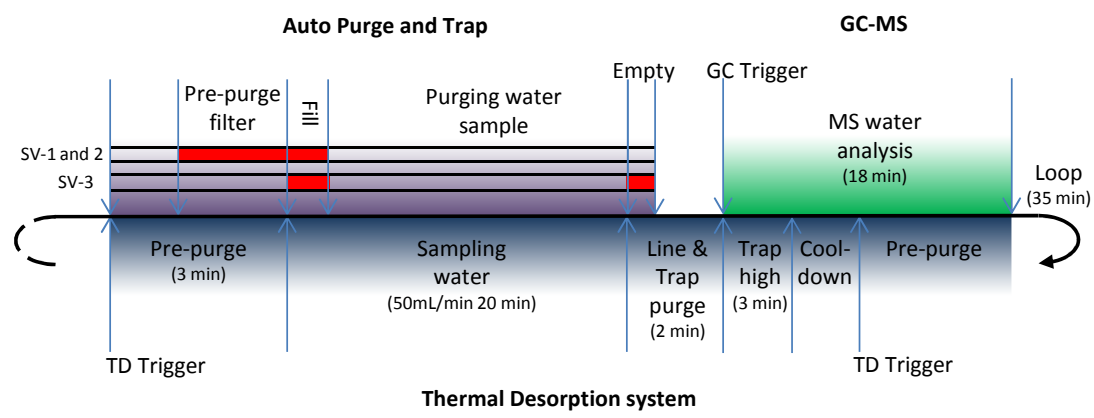

Figure 3. Graphical representation of the AutoP \& T cycle (purple shading) beginning with the trigger from the thermal desorption cycle (blue shading) and its subsequent triggering of the GC-MS run (green shading).

\section{Results}

\subsection{AutoP \& T performance}

The reproducibility of the system was tested in the laboratory pre-, during and post-research cruises. Obtaining blank samples for laboratory tests was difficult due to the ubiquitously high concentrations of VOCs, especially halogenated species, in domestic and laboratory water supplies (Milli-Q, Fisher Scientific Optima LC-MS, etc.). It was noted during fieldwork that the first few seawater samples collected from the ship's continuous supply were usually higher than average - these data points were discarded. Continual system operation with underway seawater resulted in a "conditioning" of the AutoP\&T and/or the ship's underway water supply, as suggested by the stabilisation of concentrations after 2$3 \mathrm{~h}$. Duplicate analysis of underway samples from unproduc- tive oceanic regions showed very good reproducibility ( $7 \%$ RSD for $\mathrm{CCl}_{4}, 24 \mathrm{~h}$ sampling, 7 February 2012, eastern tropical Pacific). This is due to the system being optimised to trace levels far below those present in commercially available water, and for this reason it is likely that reproducibility is actually better during shipboard deployment than during laboratory-based trials, and system performance testing should be carried out in the field. For post-cruise performance testing, seawater was collected from $3000 \mathrm{~m}$ depth in the Arctic Ocean, filtered, sparged with $\mathrm{N}_{2}$ and used as a blank matrix spiked with each compound of interest at mid-high ocean representative levels $\left(0-50 \mathrm{pmol} \mathrm{L}^{-1}\right)$. The reproducibility of the AutoP\&T ranged from between 0.1 and $20 \%$ RSD, depending on the method (see Table 1), but was $<2 \%$ RSD for the majority of compounds in $20 \mathrm{~mL}$ sample volumes. 


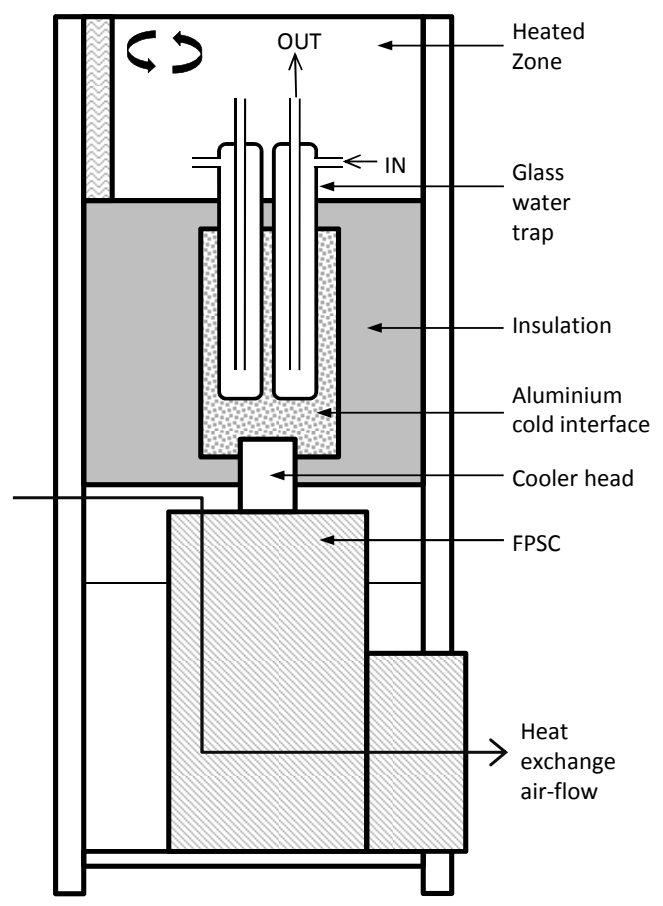

Figure 4. Schematic of the free piston Stirling cooler (FPSC) water trap. Glass water traps are cooled to $-30^{\circ} \mathrm{C}$ via a billet aluminium interface insulated using milled expanded polyurethane foam.

\subsection{Purge efficiencies}

Purge efficiencies were determined using multiple purges of spiked, blank seawater collected at $3000 \mathrm{~m}$ depth (Table 1). Water samples were run as per a usual analysis but not emptied from the purge tube at the end of the sampling time. The degassed sample was held within the tube and repeatedly analysed until no measurable difference between consecutive samples was observed. The purge efficiency was then calculated using

$\%$ purge eff. $=[\text { analyte }]_{n 1} \times 100 / \sum_{n=1}^{n}[\text { analyte }]_{n}$,

where $n$ is the number of consecutive purges of the same water sample. Two set-ups were tested for purge efficiency with either 20 or $84 \mathrm{~mL}$ sample volumes, depending on the target analytes; the results are shown in Fig. 5 . The $20 \mathrm{~mL}$ volume was optimised for VSLS and used during the Tropical Ocean tRoposphere Exchange of Reactive halogen species and Oxygenated VOC (TORERO) campaign in the eastern tropical Pacific. As halocarbons were present in seawater at a high enough concentration to be quantified in $20 \mathrm{~mL}$ samples, this smaller volume was used as it could be efficiently degassed in $20 \mathrm{~min}$. Halocarbon purge efficiencies were lower than $100 \%$ in the larger, $84 \mathrm{~mL}$ sample volume. Monoterpene concentrations observed in seawater were very low. This, combined with higher limits of detection compared to the halocarbons,
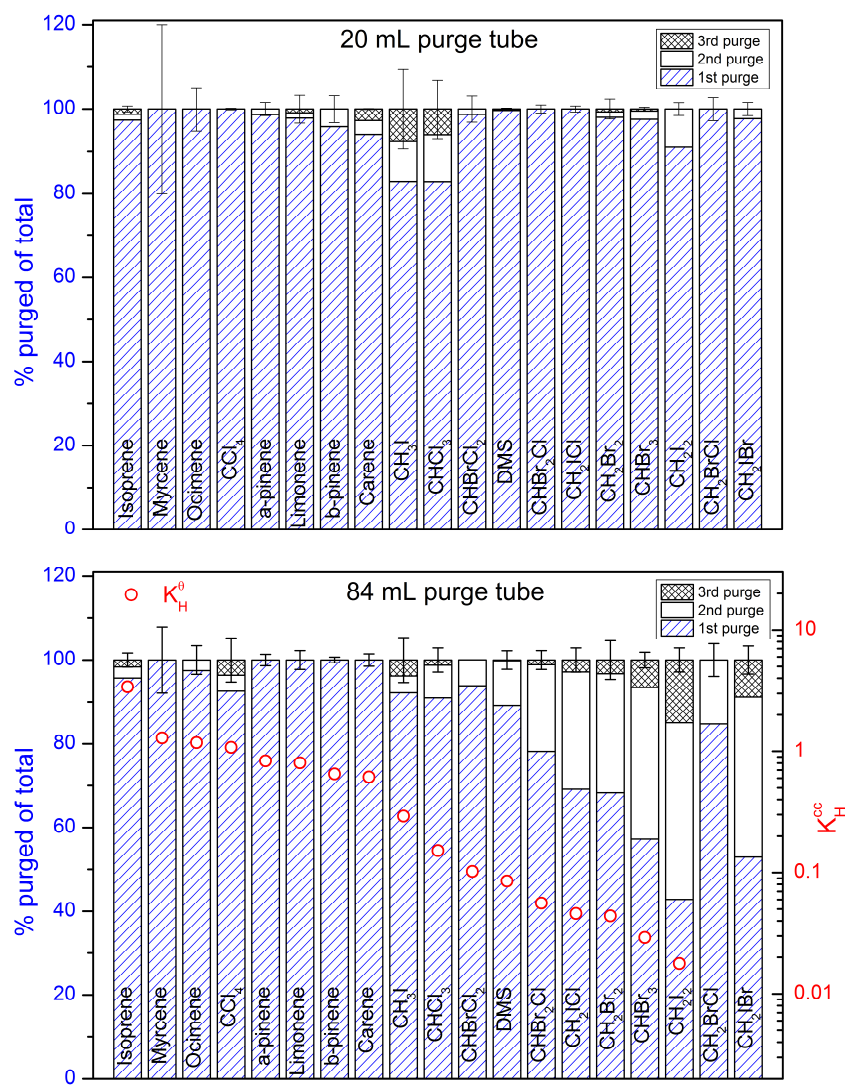

Figure 5. Purge efficiencies for $20 \mathrm{~mL}$ (top) and $84 \mathrm{~mL}$ (bottom) water samples. Blue bars represent the $\%$ purged from the sample in the first purge. Error bars show the run-to-run reproducibility of the system. For the $84 \mathrm{~mL}$ samples $K_{\mathrm{H}}^{\mathrm{cc}}$ is plotted as red circles and decreases with purge efficiency.

prompted the use of an $84 \mathrm{~mL}$ sample sparged for $30 \mathrm{~min}$. The relatively high Henry's law coefficients of the monoterpenes resulted in near $100 \%$ purge efficiency even at this large water volume. Where the analytes were not purged completely, their purge efficiencies decreased with decreasing Henry's law coefficients, as expected (Fig. 5).

\subsection{Seawater measurements}

The AutoP \& T was run continuously as an automated online instrument sampling underway surface seawater from NOAA ship Ka'imimoana during the TORERO campaign in January-February 2012. For the first 2 weeks the ship was in transit between Hawaii and the $110^{\circ} \mathrm{W}$ TAO (Tropical Atmosphere Ocean) buoy line. Afterward the underway sampling was interspersed with CTD depth profiles. To illustrate the performance of the instrument, Fig. 6 shows chloroiodomethane $\left(\mathrm{CH}_{2} \mathrm{ICl}\right)$ and diiodomethane $\left(\mathrm{CH}_{2} \mathrm{I}_{2}\right)$ concentrations measured simultaneously in seawater and air. These compounds are important components in global cycling of iodine, with combined emissions comparable to that of methyl iodide $\left(\mathrm{CH}_{3} \mathrm{I}\right)$ (Jones et al., 2010). Air abundances 

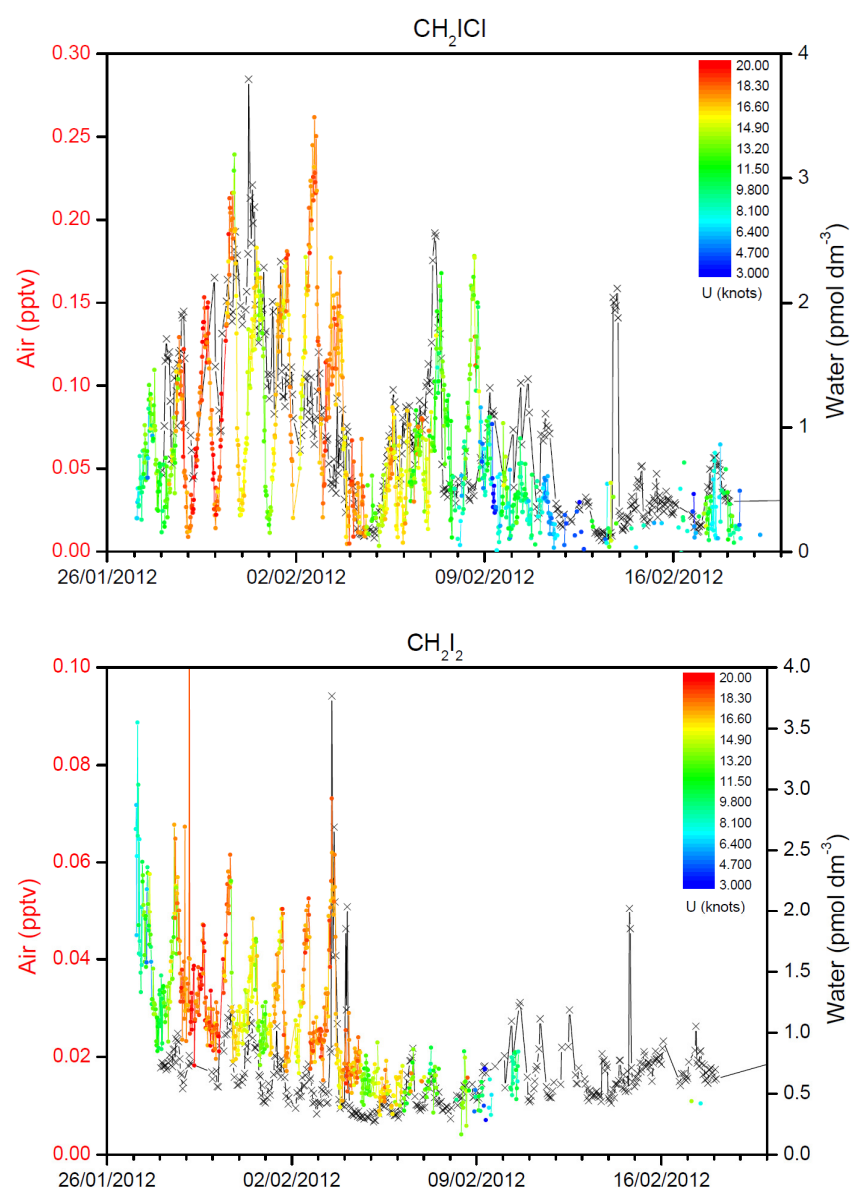

Figure 6. Example fieldwork data from the eastern tropical Pacific using the AutoP \& T system. Air concentrations (squares coloured by wind speed) are plotted with water concentrations (black crosses) for $\mathrm{CH}_{2} \mathrm{ICl}$ (top) and $\mathrm{CH}_{2} \mathrm{I}_{2}$ (bottom).

were measured using the same type of TD-GC-MS as described for the water system. Both water and air phases were calibrated using NOAA standard SX-3570 and intercalibrated between UK research institutions (Jones et al., 2011). Concentrations of all quantified halocarbons within this cylinder (34 L Essex Cryogenics) were measured as stable for $>4$ years from filling. Air concentrations of $\mathrm{CH}_{2} \mathrm{ICl}$ and $\mathrm{CH}_{2} \mathrm{I}_{2}$ were at least partly driven by wind speed and photolysis during the cruise, showing strong diurnal cycles (night-time maxima) and with higher abundances at higher wind speeds (Fig. 6). This is consistent with their short atmospheric lifetimes (Montzka et al., 2011) and the fact that their main source is (largely wind-driven) air-sea exchange. In seawater, $\mathrm{CH}_{2} \mathrm{I}_{2}$ also showed a clear diurnal cycle in synchrony with the air observations. This is the first time that a VSLS diurnal cycle has been measured in seawater, but it is also consistent with expectations, since the lifetime of $\mathrm{CH}_{2} \mathrm{I}_{2}$ in surface seawater is only a few minutes (Jones and Carpenter, 2005). This observation of diurnal cycling was only pos- sible with high temporal resolution, a low background signal and very little sample carry-over of the AutoP \& T system.

\section{Conclusions}

The AutoP \& T's low cost and simplicity make it a feasible addition to any TD-GC-MS system and it has been shown to be robust (using pinch valves in later iterations) throughout extended ship-borne sampling campaigns. Filtration of the sample was found to be a large source of potential error. Whereas halocarbons appeared robust toward filtration, DMS was more sensitive (Kiene and Slezak, 2006; Saltzman et al., 2009) and required new filter media per water sample to avoid production occurring on the filter between samples. A further modification to improve the system would be an automated system for filter changing and the addition of an optical sensor for measuring the purge tube fill volume. Other instrumental issues encountered using this system were largely a result of water vapour ingress beyond the water removal steps. Salt was found to block narrow bore tubing and mass spectrometer sensitivity decreased as water accumulated in the TD-GC system. This highlights that complete water removal is imperative for robust system operation.

The AutoP \& T approach of this study is not meant to indicate that this is necessarily the best method for seawater analysis. Equilibrator systems have advantages, such as reduced mechanical and thermal stress on the sample, and do not require extensive filtration. However, equilibrators often require more method validation and rely upon the system reaching equilibrium, whereas the AutoP \& T method can be set up and tested relatively easily, provides an absolute concentration measurement and can be applied to a large range of analytes greater than within the scope of this work.

The AutoP \& T system described here has proven capable of determining low levels of atmospherically important trace gases in the ocean. It has been successfully applied to the quantification of ocean-atmosphere fluxes with a $50 \mathrm{~min}$ temporal resolution, fast enough to capture gradients in diurnal cycling whilst maintaining a low limit of detection for short-lived gas species. Purge efficiencies were tested at $>80 \%$ for all analytes (within SD) using $20 \mathrm{~mL}$ sample volumes at $50{ }^{\circ} \mathrm{C}$ and purging with $50 \mathrm{~mL} \mathrm{~min}^{-1} \mathrm{~N}_{2}$ for $20 \mathrm{~min}$.

\section{The Supplement related to this article is available online at doi:10.5194/os-11-313-2015-supplement.}

Acknowledgements. We would like to thank NERC, NCAS, the TORERO science team and the crew of NOAA ship Ka'imimoana.

Edited by: M. Hoppema 


\section{References}

Asare, N. K., Turley, C. M., Nightingale, P. D., and Nimmo, M.: Microbially-mediated methyl iodide production in water samples from an estuarine system, J. Environ., 1, 75-83, 2012.

Beale, R., Liss, P. S., Dixon, J. L., and Nightingale, P. D.: Quantification of oxygenated volatile organic compounds in seawater by membrane inlet-proton transfer reaction/mass spectrometry, Anal. Chim. Acta, 706, 128-134, doi:10.1016/j.aca.2011.08.023, 2011.

Bouteiller, A. L., Blanchot, J., and Rodier, M.: Size distribution patterns of phytoplankton in the western Pacific: towards a generalization for the tropical open ocean, Deep-Sea Res. Pt. A, 39, 805-823, doi:10.1016/0198-0149(92)90123-B, 1992.

Butler, J. H., King, D. B., Lobert, J. M., Montzka, S. A., YvonLewis, S. A., Hall, B. D., Warwick, N. J., Mondeel, D. J., Aydin, M., and Elkins, J. W.: Oceanic distributions and emissions of short-lived halocarbons, Global Biogeochem. Cy., 21, GB1023, doi:10.1029/2006GB002732, 2007.

Carpenter, L., Malin, G., Liss, P., and Kupper, F.: Novel biogenic iodine-containing trihalomethanes and other short-lived halocarbons in the coastal East Atlantic, Global Biogeochem. Cy., 14, 1191-1204, 2000.

Carpenter, L. J. and Liss, P. S.: On temperate sources of bromoform and other reactive organic bromine gases, J. Geophys. Res.Atmos., 105, 20539-20547, 2000.

Chance, R., Baker, A. R., Küpper, F. C., Hughes, C., Kloareg, B., and Malin, G.: Release and transformations of inorganic iodine by marine macroalgae, Estuar. Coast. Shelf S., 82, 406-414, 2009.

Davis, D., Chen, G., Kasibhatla, P., Jefferson, A., Tanner, D., Eisele, F., Lenschow, D., Neff, W., and Berresheim, H.: DMS oxidation in the Antarctic marine boundary layer: Comparison of model simulations and held observations of DMS, DMSO, $\mathrm{DMSO}_{2}, \mathrm{H}_{2} \mathrm{SO}_{4(\mathrm{~g})}, \mathrm{MSA}_{(\mathrm{g})}$, and $\mathrm{MSA}_{(\mathrm{p})}$, J. Geophys. Res.Atmos., 103, 1657-1678, 1998.

DEFRA: The Water Supply (Water Quality) Regulations 2000, available at: http://dwi.defra.gov.uk/stakeholders/ guidance-and-codes-of-practice/WS(WQ)-regs-england2010. pdf (last access: 11 December 2014), 2000.

Goodwin, K., North, W., and Lidstrom, M.: Production of bromoform and dibromomethane by giant kelp: factors affecting release and comparison to anthropogenic bromine sources, Limnol. Oceanogr., 42, 1725-1734, 1997.

Groszko, W. and Moore, R.: A semipermeable membrane equilibrator for halomethanes in seawater, Chemosphere, 36, 3083-3092, doi:10.1016/S0045-6535(98)00019-8, 1998.

Happell, J. and Wallace, D.: Methyl iodide in the Greenland/Norwegian Seas and the tropical Atlantic Ocean: evidence for photochemical production, Geophys. Res. Lett., 23, 21052108, 1996.

Hughes, C., Malin, G., Turley, C., Keely, B., Nightingale, P., and Liss, P.: The production of volatile iodocarbons by biogenic marine aggregates, Limnol. Oceanogr., 53, 867-872, 2008.

Johnson, J. E.: Evaluation of a seawater equilibrator for shipboard analysis of dissolved oceanic trace gases, Anal. Chim. Acta, 395, 119-132, doi:10.1016/S0003-2670(99)00361-X, 1999.

Jones, C. and Carpenter, L.: Solar photolysis of $\mathrm{CH}_{2} \mathrm{I}_{2}, \mathrm{CH}_{2} \mathrm{ICl}$, and $\mathrm{CH}_{2} \mathrm{IBr}$ in water, saltwater, and seawater, Environ. Sci. Technol., 39, 6130-6137, 2005.
Jones, C., Hornsby, K., Sommariva, R., Dunk, R., Von Glasow, R., McFiggans, G., and Carpenter, L.: Quantifying the contribution of marine organic gases to atmospheric iodine, Geophys. Res. Lett., 37, L18804, doi:10.1029/2010GL043990, 2010.

Jones, C. E., Hornsby, K. E., Dunk, R. M., Leigh, R. J., and Carpenter, L. J.: Coastal measurements of short-lived reactive iodocarbons and bromocarbons at Roscoff, Brittany during the RHaMBLe campaign, Atmos. Chem. Phys., 9, 8757-8769, doi:10.5194/acp-9-8757-2009, 2009.

Jones, C. E., Andrews, S. J., Carpenter, L. J., Hogan, C., Hopkins, F. E., Laube, J. C., Robinson, A. D., Spain, T. G., Archer, S. D., Harris, N. R. P., Nightingale, P. D., O'Doherty, S. J., Oram, D. E., Pyle, J. A., Butler, J. H., and Hall, B. D.: Results from the first national UK inter-laboratory calibration for very short-lived halocarbons, Atmos. Meas. Tech., 4, 865-874, doi:10.5194/amt4-865-2011, 2011.

Kameyama, S., Tanimoto, H., Inomata, S., Tsunogai, U., Ooki, A., Takeda, S., Obata, H., Tsuda, A., and Uematsu, M.: Highresolution measurement of multiple volatile organic compounds dissolved in seawater using equilibrator inlet-proton transfer reaction-mass spectrometry (EI-PTR-MS), Mar. Chem., 122, 5973, doi:10.1016/j.marchem.2010.08.003, 2010.

Kameyama, S., Yoshida, S., Tanimoto, H., Inomata, S., Suzuki, K., and Yoshikawa-Inoue, H.: High-resolution observations of dissolved isoprene in surface seawater in the Southern Ocean during austral summer 2010-2011, J. Oceanogr., 70, 225-239, 2014.

Kiene, R. P. and Slezak, D.: Low dissolved DMSP concentrations in seawater revealed by small-volume gravity filtration and dialysis sampling, Limnol. Oceanogr.-Meth., 4, 80-95, 2006.

Ledyard, K. M. and Dacey, J. W.: Dimethylsulfide production from dimethylsulfoniopropionate by a marine bacterium, Mar. Ecol.Prog. Ser., 110, 95-103, 1994.

Leedham, E. C., Hughes, C., Keng, F. S. L., Phang, S.-M., Malin, G., and Sturges, W. T.: Emission of atmospherically significant halocarbons by naturally occurring and farmed tropical macroalgae, Biogeosciences, 10, 3615-3633, doi:10.5194/bg-10-36152013, 2013.

Leifer, I., Patro, R. K., and Bowyer, P.: A study on the temperature variation of rise velocity for large clean bubbles, J. Atmos. Ocean. Tech., 17, 1392-1402, 2000.

Lidster, R. T., Hamilton, J. F., Lee, J. D., Lewis, A. C., Hopkins, J. R., Punjabi, S., Rickard, A. R., and Young, J. C.: The impact of monoaromatic hydrocarbons on $\mathrm{OH}$ reactivity in the coastal UK boundary layer and free troposphere, Atmos. Chem. Phys., 14, 6677-6693, doi:10.5194/acp-14-6677-2014, 2014.

Loose, B., Stute, M., Alexander, P., and Smethie, W. M.: Design and deployment of a portable membrane equilibrator for sampling aqueous dissolved gases, Water Resour. Res., 45, W00D34, doi:10.1029/2008WR006969, 2009.

McFiggans, G., Bale, C. S. E., Ball, S. M., Beames, J. M., Bloss, W. J., Carpenter, L. J., Dorsey, J., Dunk, R., Flynn, M. J., Furneaux, K. L., Gallagher, M. W., Heard, D. E., Hollingsworth, A. M., Hornsby, K., Ingham, T., Jones, C. E., Jones, R. L., Kramer, L. J., Langridge, J. M., Leblanc, C., LeCrane, J.-P., Lee, J. D., Leigh, R. J., Longley, I., Mahajan, A. S., Monks, P. S., Oetjen, H., Orr-Ewing, A. J., Plane, J. M. C., Potin, P., Shillings, A. J. L., Thomas, F., von Glasow, R., Wada, R., Whalley, L. K., and Whitehead, J. D.: Iodine-mediated coastal particle formation: an overview of the Reactive Halogens in the Marine Boundary 
Layer (RHaMBLe) Roscoff coastal study, Atmos. Chem. Phys., 10, 2975-2999, doi:10.5194/acp-10-2975-2010, 2010.

Montzka, S., Reimann, S., O’Doherty, S., Engel, A., Krüger, K., and Sturges, W.: Ozone-depleting substances (ODSs) and related chemicals, World Meteorological Organization, Geneva, Switzerland, 1-112, 2011.

Ordóñez, C., Lamarque, J.-F., Tilmes, S., Kinnison, D. E., Atlas, E. L., Blake, D. R., Sousa Santos, G., Brasseur, G., and Saiz-Lopez, A.: Bromine and iodine chemistry in a global chemistry-climate model: description and evaluation of very short-lived oceanic sources, Atmos. Chem. Phys., 12, 1423-1447, doi:10.5194/acp12-1423-2012, 2012.

Quack, B., Atlas, E., Petrick, G., Stroud, V., Schauffler, S., and Wallace, D.: Oceanic bromoform sources for the tropical atmosphere, Geophys. Res. Lett, 31, L23S05, doi:10.1029/2004GL020597, 2004.

Quack, B., Peeken, I., Petrick, G., and Nachtigall, K.: Oceanic distribution and sources of bromoform and dibromomethane in the Mauritanian upwelling, J. Geophys. Res.-Oceans, 112, C10006, doi:10.1029/2006JC003803, 2007.

Raimund, S., Quack, B., Bozec, Y., Vernet, M., Rossi, V., Garçon, V., Morel, Y., and Morin, P.: Sources of short-lived bromocarbons in the Iberian upwelling system, Biogeosciences, 8, 15511564, doi:10.5194/bg-8-1551-2011, 2011.

Read, K. A., Mahajan, A. S., Carpenter, L. J., Evans, M. J., Faria, B. V. E., Heard, D. E., Hopkins, J. R., Lee, J. D., Moller, S. J., Lewis, A. C., Mendes, L., McQuaid, J. B., Oetjen, H., Saiz-Lopez, A., Pilling, M. J., and Plane, J. M. C.: Extensive halogen-mediated ozone destruction over the tropical Atlantic Ocean, Nature, 453, 1232-1235, 2008.

Richter, U. and Wallace, D.: Production of methyl iodide in the tropical Atlantic Ocean, Geophys. Res. Lett., 31, L23S03, doi:10.1029/2004GL020779, 2004.

Saiz-Lopez, A., Lamarque, J.-F., Kinnison, D. E., Tilmes, S., Ordóñez, C., Orlando, J. J., Conley, A. J., Plane, J. M. C., Mahajan, A. S., Sousa Santos, G., Atlas, E. L., Blake, D. R., Sander, S. P., Schauffler, S., Thompson, A. M., and Brasseur, G.: Estimating the climate significance of halogen-driven ozone loss in the tropical marine troposphere, Atmos. Chem. Phys., 12, 3939-3949, doi:10.5194/acp-12-3939-2012, 2012.

Saltzman, E. S., De Bruyn, W. J., Lawler, M. J., Marandino, C. A., and McCormick, C. A.: A chemical ionization mass spectrometer for continuous underway shipboard analysis of dimethylsulfide in near-surface seawater, Ocean Sci., 5, 537-546, doi:10.5194/os-5-537-2009, 2009.
Sander, R.: Compilation of Henry's law constants for inorganic and organic species of potential importance in environmental chemistry, Max-Planck Institute of Chemistry, 1999.

Santos, G. S. and Rast, S.: A global model study of natural bromine sources and the effects on tropospheric chemistry using MOZART4, J. Atmos. Chem., 70, 69-89, doi:10.1007/s10874013-9252-y, 2013.

Schall, C., Laturnus, F., and Heumann, K.: Biogenic volatile organoiodine and organobromine compounds released from polar macroalgae, Chemosphere, 28, 1315-1324, 1994.

Sturges, W., Sullivan, C., Schnell, R., Heidt, L., and Pollock, W.: Bromoalkane production by Antarctic ice algae, Tellus B, 45, 120-126, 1993.

Thompson, T., Fawell, J., Kunikane, S., Jackson, D., Appleyard, S., Callan, P., Bartram, J., and Kingston, P.: Chemical Safety of Drinking-Water, World Health Organization, 2007.

Tokarczyk, R. and Moore, R.: Production of volatile organohalogens by phytoplankton cultures, Geophys. Res. Lett., 21, 285288, 1994.

US EPA: Title 40 - Protection of Environment, Code of Federal Regulations (annual edition), 2010.

von Glasow, R., von Kuhlmann, R., Lawrence, M. G., Platt, U., and Crutzen, P. J.: Impact of reactive bromine chemistry in the troposphere, Atmos. Chem. Phys., 4, 2481-2497, doi:10.5194/acp-42481-2004, 2004.

Yang, M., Beale, R., Liss, P., Johnson, M., Blomquist, B., and Nightingale, P.: Air-sea fluxes of oxygenated volatile organic compounds across the Atlantic Ocean, Atmos. Chem. Phys., 14, 7499-7517, doi:10.5194/acp-14-7499-2014, 2014.

Yang, X., Cox, R., Warwick, N., Pyle, J., Carver, G., O’Connor, F., and Savage, N.: Tropospheric bromine chemistry and its impacts on ozone: a model study, J. Geophys. Res., 110, D23311, doi:10.1029/2005JD006244, 2005.

Zuend, A., Marcolli, C., Luo, B. P., and Peter, T.: A thermodynamic model of mixed organic-inorganic aerosols to predict activity coefficients, Atmos. Chem. Phys., 8, 4559-4593, doi:10.5194/acp8-4559-2008, 2008.

Zuend, A., Marcolli, C., Booth, A. M., Lienhard, D. M., Soonsin, V., Krieger, U. K., Topping, D. O., McFiggans, G., Peter, T., and Seinfeld, J. H.: New and extended parameterization of the thermodynamic model AIOMFAC: calculation of activity coefficients for organic-inorganic mixtures containing carboxyl, hydroxyl, carbonyl, ether, ester, alkenyl, alkyl, and aromatic functional groups, Atmos. Chem. Phys., 11, 9155-9206, doi:10.5194/acp11-9155-2011, 2011. 